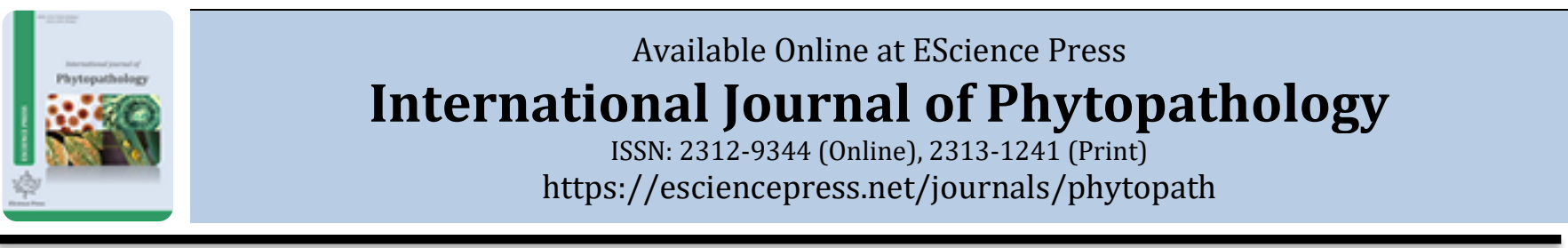

\title{
EFFECTS OF PH AND AERATION ON SCLEROTIUM ROLFSII SACC. MYCELIAL GROWTH, SCLEROTIAL PRODUCTION AND GERMINATION
}

a,b,cFakher Ayed*, cHayfa Jabnoun-Khiareddine, cRania Aydi-Ben-Abdallah, cMejda Daami-Remadi

${ }^{a}$ Technical Centre of Organic Agriculture, Chott-Meriam, Sousse, Tunisia.

${ }^{\boldsymbol{b}}$ National Agronomic Institute of Tunisia, 1082 Tunis, University of Carthage, Tunisia.

c UR13AGR09-Integrated Horticultural Production in the Tunisian Centre-East, Regional Research Centre on Horticulture and Organic Agriculture, University of Sousse, Chott-Mariem, Tunisia.

*Corresponding Author Email: ayedfakher@yahoo.fr

\section{A B S T R A C T}

Sclerotium rolfsii is one of the devastating soilborne fungus responsible for significant plant losses. The effects of $\mathrm{pH}$ and aeration on pathogen mycelial growth, sclerotial production and germination were investigated for three Tunisian isolates. Optimal mycelial growth occurred at $\mathrm{pH} 6$ for $\mathrm{Sr} 2$ and $\mathrm{Sr} 3$ isolates and at pH 6-7 for Sr1. Dry mycelial growth was optimum at $\mathrm{pH}$ values ranging between 4 and 7 . Sclerotial initiation started on the $3^{\text {rd }}$ day of incubation at all $\mathrm{pH}$ values tested and mature sclerotia were formed after 6 to 12 days. Optimal sclerotial production was noted at $\mathrm{pH} 5$. The dry weight of 100 sclerotia varied depending on isolates and $\mathrm{pH}$ and occurred at $\mathrm{pH}$ range 4-7. At $\mathrm{pH}$ 9, mycelial growth, sclerotial production and dry weight of 100 sclerotia were restricted. The optimum sclerotial germination, noted after $24 \mathrm{~h}$ of incubation, varied depending on isolates and $\mathrm{pH}$ and occurred at $\mathrm{pH} 4-9$. Mycelial growth was optimum in aerated plates with a significant isolates $\mathrm{x}$ aeration treatments interaction. Sclerotial initiation occurred at the $3^{\text {rd }}$ day of incubation and mature sclerotia were observed after 6-9 days. Sclerotial development was very slow in completely sealed plates and dark sclerotia were produced only after 15 days of incubation. The highest sclerotial yields were noted in aerated plates. The highest dry weight of 100 sclerotia for Sr 1 isolate was recorded in $1 / 2$ sealed, no sealed and completely sealed plates, while for $\mathrm{Sr} 2$, it was noted in $1 / 2$ and $2 / 3$ sealed plates. For Sr3, the maximum dry weight of 100 sclerotia was recorded in $1 / 2,2 / 3$ and completely sealed plates. Germination of $S$. rolfsii sclerotia, after $24 \mathrm{~h}$ of incubation, did not vary significantly depending on aeration treatments and ranged from 90 to $100 \%$ for all isolates.

Keywords: Aeration, germination, mycelial growth, pH, sclerotial production, Sclerotium rolfsii

\section{INTRODUCTION}

Climate change represents one of the most serious challenges facing humanity in the $21^{\text {st }}$ Century, inducing temperature rise, rainfall variation together with a frequency and an intensity of extreme weather events (Radhouane, 2013). It can affect both crop and livestock production systems in most regions (OECD, 2015). Moreover, changes in environmental conditions are expected to affect the development of plant pathogens and their survival rates and to modify host susceptibility leading to the emergence of new diseases (Anderson et al., 2004; Elad and Pertot, 2014). Thus, new, emerging, and re-emerging plant diseases threatening various crops have been reported in Tunisia within the last years (Hibar et al., 2007; Rhouma et al., 2010; Gaaliche et al., 2017; Jabnoun-Khiareddine et al., 2018). Among those diseases, Southern blight, caused by Sclerotium rolfsii Sacc., has become a serious problem causing severe plant and yield losses in a wide range of crops. This pathogen can cause dry-seed yield loss of up to $53.4 \%$ on cowpea (Fery and Dukes, 2002) and about 5 to $20 \%$ of crop loss on peppermint (Singh and Singh, 2004). Moreover, it is considered as major threat to tomato and artichoke crops leading, respectively, to 10$45 \%$ (Banyal et al., 2008) and $60 \%$ plant losses (McCarter, 1984).

$S$. rolfsii is a well-known polyphagous, ubiquitous, omnivorous and most destructive soilborne fungus infecting more than 500 plant species belonging to about 100 botanical families (Aycock, 1966; Anahosur, 2001). The 
fungus penetrates, infects plant tissues at or near the soil surface and produces a considerable white cottony threadlike mycelium on basal plant parts (Punja, 1985). Dark brown lesions appear on infected stems just below the soil surface and/or on roots leading to drooping and wilting of leaves and gradual wilting of severely infected plants (Kator et al., 2015). Sclerotia are produced on the mycelium and started out white to tan and become dark-brown to black at maturity. These sclerotia are the main over-wintering structures and represent the primary inoculum for disease development under favorable conditions (Punja, 1985).

This pathogen has been first reported in tropical and subtropical countries and has been recently detected in North Africa. In Tunisia, this pathogen was first observed on olive trees in 2001 (Boulila, 2001), on potato in 2006 (Daami-Remadi et al., 2007) and on apple trees in 2012 (Kalai-Grami et al., 2013). Mycelial growth and sclerotial production of this fungus are influenced by many abiotic factors including temperature, $\mathrm{pH}$, and nutrients (Punja, 1985; Daami-Remadi et al., 2010; Maurya et al., 2010; Ayed et al., 2018). In fact, in old investigations (Aycock, 1966; Sharma and Kaushal, 1979; Punja, 1985), pathogen mycelial growth was reported to be markedly less above $\mathrm{pH}$ 8. S. rolfsii is also considered as an air-loving organism and sandy soils are, thus, more suitable for its growth (Taubenhaus, 1919). However, some recent studies indicated that $\mathrm{pH}$ values varying from 5 to 6 are optimal for its mycelial growth (Sarker et al., 2013).

The influence of some abiotic factors on S. rolfsii growth and survival was widely investigated in previous works where mycelial growth, sclerotial production and germination were separately considered in those studies (Hussain et al., 2003; Kumar et al., 2008; Maurya et al., 2010; Basamma et al., 2012; Sarker et al., 2013). However, researches focused on all physiological parameters together and the relationship between environmental conditions, pathogen growth and persistence are still lacking. Therefore, the objective of this study was to provide a more detailed information on the effects of medium $\mathrm{pH}$ and aeration on mycelial growth, sclerotial production and germination of three selected Tunisian $S$. rolfsii isolates.

\section{MATERIALS AND METHODS}

Pathogen isolates: Three $S$. rolfsii isolates were used in the current investigation. $\mathrm{Sr} 2$ and $\mathrm{Sr} 3$ were recovered from rotted potato tubers and $\mathrm{Sr} 1$ was isolated from artichoke plants showing stem rot symptoms. Identification was based on previously published descriptions of Sclerotium rolfsii (Mordue, 1988) as indicated in Ayed et al. (2018). Pathogenicity was confirmed by inoculation of healthy potato (cv. Spunta) tubers with an agar plug colonized by the pathogen (Daami-Remadi et al., 2010).

Isolates were held in the Phytopathology laboratory at the Regional Research Centre on Horticulture and Organic Agriculture of Chott-Mariem, Tunisia. Prior to use, isolates were grown on Potato Dextrose Agar (PDA) medium for one week at $25{ }^{\circ} \mathrm{C}$ and in the dark.

Effect of pH on pathogen mycelial growth and on sclerotial production and germination

Effect on radial mycelial growth and sclerotial production: To examine the effect of $\mathrm{pH}$ on $S$. rolfsii mycelial growth, sterile double-strength PDA was mixed with an equal volume of buffer to obtain the desired medium concentration. The $\mathrm{pH}$ was adjusted to 4-7 and 7-9 with citrate phosphate $(0.05 \mathrm{M}$ citric acid, $0.1 \mathrm{M}$ $\mathrm{Na}_{2} \mathrm{HPO}_{4}-7 \mathrm{H}_{2} \mathrm{O}$ ) and Tris (hydroxymethyl) aminoethane (0.1 M Tris, $0.1 \mathrm{M} \mathrm{HCl}$ ) buffers, respectively (Gomori, 1955). Mycelial plugs (6 $\mathrm{mm}$ in diameter), cut from the margin of 7-day-old colonies, were placed in the center of Petri plates ( $90 \mathrm{~mm}$ in diameter) containing PDA medium modified at the tested $\mathrm{pH}$ value and amended with streptomycin sulfate $(300 \mathrm{mg} / \mathrm{L} \mathrm{w} / \mathrm{v})$. Inoculated plates were incubated in the dark at $30^{\circ} \mathrm{C}$ for 3 days (Ayed et al., 2018). The diameters of the resulting colonies were measured after 24,48 and $72 \mathrm{~h}$ of inoculation and the radial growth rate $(\mathrm{mm} /$ day) was calculated.

The same cultures were further incubated for an additional 21 days. During this period, sclerotial production was monitored and determined at 3-day intervals (Maurya et al., 2010). For the monitoring of sclerotial production, mature sclerotia were removed with a sharp scalpel, placed in fine mesh nylon bags and washed thoroughly with Sterile Distilled Water (SDW) to remove agar debris. They were counted and the average number of mature sclerotia produced per plate was determined. After counting, sclerotia were placed on predried and weighed Whatman grade 1 qualitative filter papers and incubation at $70^{\circ} \mathrm{C}$ for $48 \mathrm{~h}$. The dry weight of 100 sclerotia per plate was determined.

For all parameters noted, ten replicate plates were used per individual treatment (per isolate and per $\mathrm{pH}$ tested). Effect on mycelium dry weight: In order to study the effect of $\mathrm{pH}$ on mycelium dry weight, $15 \mathrm{ml}$ of Potato Dextrose Broth (PDB) medium adjusted at the different $\mathrm{pH}$ values (4-9) were poured into 150 ml-flasks. The 
medium was aseptically inoculated with mycelial plugs (6 $\mathrm{mm}$ in diameter) cut from 7-day-old $S$. rolfsii colonies. Flasks were incubated in the dark at $30^{\circ} \mathrm{C}$ (Ayed et al., 2018). After 5 days of incubation, the growing mycelial mats were filtered through Whatman grade 1 qualitative filter papers, washed thoroughly with SDW, dried at $60^{\circ} \mathrm{C}$ for 3 days and weighed immediately on an analytical electrical balance. Ten replicate flasks were used per individual treatment (per isolate and per $\mathrm{pH}$ value).

Effect on sclerotial germination: Similarly sized and mature sclerotia (21-day-old) were used in this experiment. Ten sclerotia were placed onto Petri plates (90 $\mathrm{mm}$ in diameter) containing PDA medium adjusted at the different tested $\mathrm{pH}$ values (4-9) and incubated in the dark at $30{ }^{\circ} \mathrm{C}$ (Ayed et al., 2018). Germination was determined after 24, 48 and $72 \mathrm{~h}$ of incubation by examining each sclerotium for any outgrowing hyphae when observed under a binocular microscope. A sclerotium was considered germinated when the outgrowing hyphae were equal to or greater than its diameter and the percentage of germinated sclerotia per plate was recorded. Ten replicate plates were used per individual treatment (Ayed et al., 2018).

Effect of aeration on pathogen mycelial growth and on sclerotial production and germination: To assess the effect of aeration on the mycelial growth of $S$. rolfsii isolates as well as their sclerotial production and germination, PDA plates ( $90 \mathrm{~mm}$ in diameter) were inoculated each in their center with a mycelial plug $(6 \mathrm{~mm}$ in diameter) cut from a 7-day-old colonies, and wrapped with parafilm in the following manners: no sealing, $1 / 2,2 / 3$, or complete sealing (Maurya et al., 2010). Petri plates were incubated in the dark at $30^{\circ} \mathrm{C}$ (Ayed et al., 2018). The radial growth rate ( $\mathrm{mm} /$ day), the sclerotial development, production and germination were evaluated as described above. All the treatments were replicated ten times.

Statistical analysis: ANOVA analyses were performed following a completely randomized factorial design where fungal treatment ( $S$. rolfsii isolates) and tested factors ( $\mathrm{pH}$ or aeration) were the two fixed factors. Ten replicates were used per individual treatment and means were separated using Fisher's protected LSD or Students Neuman Keuls tests (at $P \leq 0.05$ ). All the experiments were repeated twice with 10 replicates per individual treatment for each. For each bioassay, the mean data was presented in the current study. Statistical analyses were performed using SPSS software version 20.

\section{RESULTS}

\section{Effect of pH on S. rolfsii growth and survival}

Effect on radial mycelial growth: After 3 days of incubation at $30^{\circ} \mathrm{C}$ on PDA medium, the mycelial growth of S. rolfsii varied significantly (at $P \leq 0.05$ ) depending on $\mathrm{pH}$ of the culture medium and pathogen isolates; moreover, a significant interaction was also noted between these two factors. In fact, as shown in Table 1 , all $S$. rolfsii isolates were found able to grow over a range of $\mathrm{pH}$ from 4 to 9 (Figure 1). Optimal growth occurred at $\mathrm{pH} 6$ for $\mathrm{Sr} 2$ and $\mathrm{Sr} 3$ isolates with an average growth of 28.93 and $28.23 \mathrm{~mm} /$ day, respectively, whereas Sr1 showed its highest mycelial extension at $\mathrm{pH} 6$ and 7 with an average growth rate of 30.19 and $29.71 \mathrm{~mm} /$ day, respectively. However, it should be noted that $S$. rolfsii mycelial growth was significantly restricted (at $P \leq 0.05$ ) at $\mathrm{pH} 9$ for all isolates (15.94-16.89 $\mathrm{mm} /$ day) compared to the other $\mathrm{pH}$ values (Table 1, Figure 1). For all $\mathrm{pH}$ values tested, the mycelial growth of $\mathrm{Sr} 1$ was significantly higher than that of Sr2 and Sr3.

Table 1. Effect of $\mathrm{pH}$ of Potato Dextrose Agar medium on the radial growth of three Sclerotium rolfsii isolates recorded after 3 days of incubation at $30^{\circ} \mathrm{C}$ in the dark.

\begin{tabular}{cllll}
\hline \multirow{2}{*}{ pHvalue } & \multicolumn{3}{c}{ Radial growth $(\mathrm{mm} /$ day) } & Mean radial growth per $\mathrm{pH}$ \\
\cline { 2 - 4 } value $\left(\mathrm{mm} /\right.$ day) $^{1}$ & Sr1 & Sr2 & Sr3 & $27.74 \mathrm{~cd}$ \\
5 & $28.39 \mathrm{~b}$ & $27.61 \mathrm{~b}$ & $27.23 \mathrm{~b}$ & $27.94 \mathrm{bc}$ \\
6 & $28.39 \mathrm{~b}$ & $28.08 \mathrm{~b}$ & $27.36 \mathrm{~b}$ & $29.12 \mathrm{a}$ \\
7 & $30.19 \mathrm{a}$ & $28.93 \mathrm{a}$ & $28.23 \mathrm{a}$ & $28.29 \mathrm{~b}$ \\
8 & $29.71 \mathrm{a}$ & $27.84 \mathrm{~b}$ & $27.33 \mathrm{~b}$ & $27.47 \mathrm{~d}$ \\
9 & $28.06 \mathrm{~b}$ & $27.89 \mathrm{~b}$ & $26.46 \mathrm{c}$ & $16.41 \mathrm{e}$ \\
Mean radial growth per isolate & $16.4 \mathrm{c}$ & $15.94 \mathrm{c}$ & $16.89 \mathrm{~d}$ & \\
(mm/day) $^{2}$ & $26.86 \mathrm{a}$ & $26.05 \mathrm{~b}$ & $25.58 \mathrm{c}$ & - \\
\hline
\end{tabular}

${ }^{1}$ Mean radial growth per $\mathrm{pH}$ value for the three isolates combined, ${ }^{2}$ Mean radial growth per isolate for all $\mathrm{pH}$ values combined,

${ }^{*} \mathrm{LSD}(\mathrm{pH} \times S$. rolfsii isolates $)=0.53 \mathrm{~mm} /$ day at $P \leq 0.05,{ }^{*}$ For each isolate and each mean radial growth (per pH value or per 
isolate), values followed by the same letter are not significantly different according to Duncan Multiple Range test (at $P \leq$ $0.05)$.

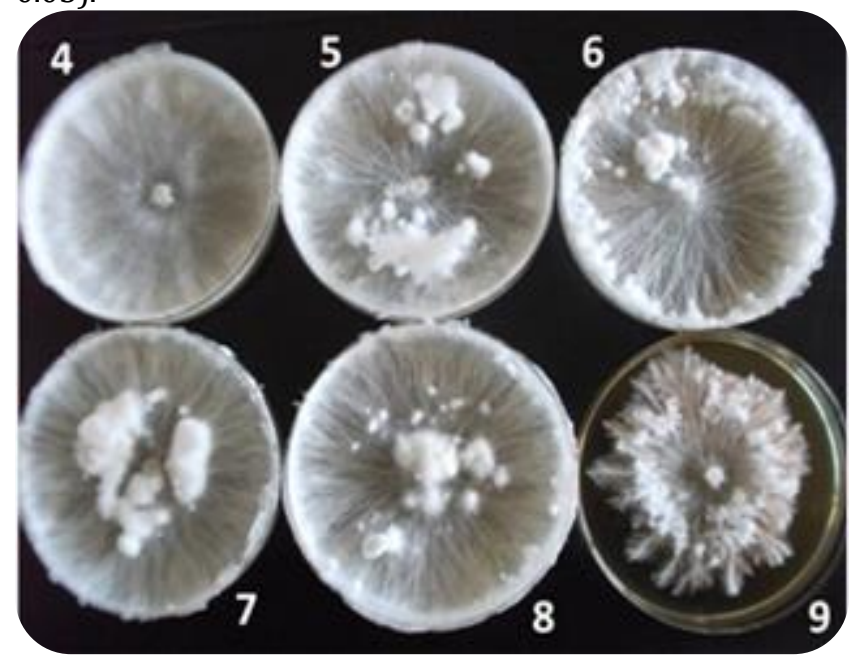

Figure 1. Colonies of Sclerotium rolfsii isolate Sr1 formed after 3 days of incubation at $30{ }^{\circ} \mathrm{C}$ on PDA medium adjusted at different $\mathrm{pH}$ values.

Effect on mycelium dry weight: All tested S. rolfsii isolates were shown able to grow on $\mathrm{pH}$-adjusted PDB medium, at $\mathrm{pH}$ range $4-9$, and their mycelial dry weights varied significantly depending on $\mathrm{pH}$ values. As no significant interaction was noted between these two factors, data was presented and commented considering each factor separately as given in Figure 2 (A, B). In fact, for all S. rolfsii isolates combined (Figure $2 \mathrm{~A}$ ), fungal dry biomass was optimum at $\mathrm{pH}$ values ranging from 4 to 7 with an average mycelial dry weight varying between 249.87 and $260.17 \mathrm{mg}$, respectively. However, the lowest records were noted at $\mathrm{pH}$ 9. For all $\mathrm{pH}$ values combined (Figure 2B), the isolate Sr3 showed the highest mycelial dry weight (263.58 $\mathrm{mg}$ ) followed by Sr2 (249.26 $\mathrm{mg}$ ) and Sr1 (203.68 mg).

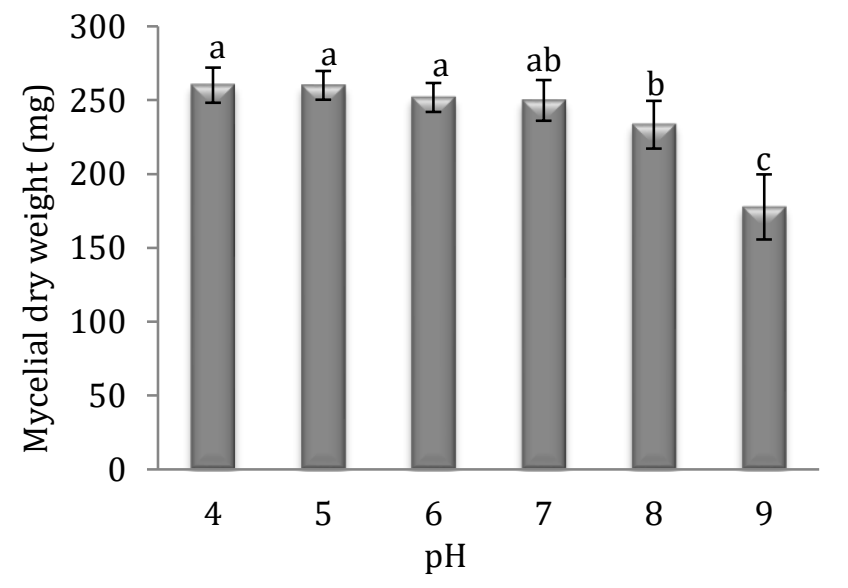

Effect on sclerotial formation and production: As shown in Table 2, pathogen sclerotial formation was affected by $\mathrm{pH}$ values. In fact, sclerotial initiation of all isolates started on the $3^{\text {rd }}$ day of incubation from the hyphal branching and anastomosis, followed by hyphal aggregation and network formation at all $\mathrm{pH}$ values tested (Figure 1). The network developed to so-called initial and grew to white immature sclerotium on the 6$9^{\text {th }}$ days of incubation at $\mathrm{pH} 4-8$ and after the $9^{\text {th }}$ day for all isolates at $\mathrm{pH}$ 9. At $\mathrm{pH}$ range 4-6, dark sclerotia were formed quickly after 6 to 12 days of incubation. Nevertheless, at pH 7-9, they were observed on the $12^{\text {th }}$ day (Table 2). The number of mature sclerotia of $S$. rolfsii per plate, noted after 21 days of incubation at $30^{\circ} \mathrm{C}$ on PDA medium, varied significantly depending on tested isolates and $\mathrm{pH}$ values; a significant interaction was also noted between these both fixed factors $(P \leq 0.05)$.

As presented in Table 3, all S. rolfsii isolates were shown able to produce dark sclerotia when grown on PDA medium adjusted at the different $\mathrm{pH}$ values. $\mathrm{Sr} 1$ and $\mathrm{Sr} 3$ isolates showed optimal sclerotial production at $\mathrm{pH} 5$ which was estimated at 193.2 and 150 sclerotia/plate, respectively. For Sr2, sclerotial production was significantly similar at $\mathrm{pH} 4$ and $\mathrm{pH} 5$ with an average of 137.2 and 168.6 mature sclerotia/plate, respectively. The lowest sclerotial production was noted on cultures grown on PDA adjusted at $\mathrm{pH} 9$ for $\mathrm{Sr} 1, \mathrm{Sr} 2$ and $\mathrm{Sr} 3$ isolates with an average of sclerotial production estimated at 63.6, 59.4, and 31.8 sclerotia/plate, respectively (Table 3 ). For all $\mathrm{pH}$ values combined (pooled data of all $\mathrm{pH}$ values tested), $\mathrm{Sr} 1$ and $\mathrm{Sr} 2$ isolates produced more mature sclerotia than $\mathrm{Sr} 3$ at the same incubation duration.

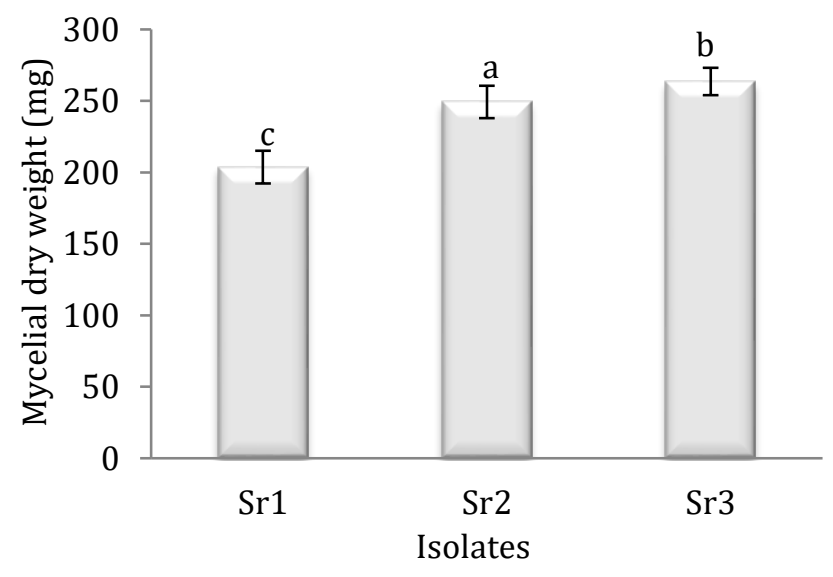


Figure 2. Effect of pH of Potato Dextrose Broth medium on the mycelial dry weight of three Sclerotium rolfsii isolates recorded after 5 days of incubation at $30^{\circ} \mathrm{C}$ in the dark.

Bars sharing the same letter are not significantly different according to Duncan Multiple Range test (at $P \leq 0.05$ ).

Table 2. Effect of pH of Potato Dextrose Agar medium on the sclerotial development of three Sclerotium rolfsii isolates noted after 21 days of incubation at $30^{\circ} \mathrm{C}$ in the dark.

\begin{tabular}{ccccc}
\hline \multirow{2}{*}{ pH value } & Isolates & \multicolumn{3}{c}{ Days after incubation } \\
\cline { 3 - 5 } & & First initials & White sclerotia & Dark mature sclerotia \\
\hline \multirow{2}{*}{4} & Sr1 & 3 & 6 & 9 \\
& Sr2 & 3 & 6 & 9 \\
& Sr3 & 3 & - & 9 \\
5 & Sr1 & 3 & 6 & 12 \\
& Sr2 & 3 & 6 & 9 \\
& Sr3 & 3 & 6 & 9 \\
6 & Sr1 & 3 & 6 & 12 \\
& Sr2 & 3 & 6 & 12 \\
& Sr3 & 3 & 9 & 12 \\
7 & Sr1 & 3 & 6 & 12 \\
& Sr2 & 3 & 9 & 12 \\
& Sr3 & 3 & 6 & 12 \\
& Sr1 & 3 & 6 & 12 \\
& Sr2 & 3 & 6 & 12 \\
& Sr3 & 3 & 6 & 12 \\
\hline
\end{tabular}

Table 3. Effect of pH of Potato Dextrose Agar medium on the number of sclerotia produced by three Sclerotium rolfsii isolates after 21 days of incubation at $30^{\circ} \mathrm{C}$ in the dark.

\begin{tabular}{clllc}
\hline \multirow{2}{*}{ pH value } & \multicolumn{3}{c}{ Number of sclerotia per plate } & \multicolumn{2}{c}{$\begin{array}{c}\text { Mean number of sclerotia } \\
\text { per } \mathrm{pH}^{1}\end{array}$} \\
\cline { 2 - 4 } & Sr1 & Sr2 & Sr3 & $117.13 \mathrm{c}$ \\
5 & $106.6 \mathrm{c}$ & $137.2 \mathrm{ab}$ & $107.6 \mathrm{~b}$ & $170.6 \mathrm{a}$ \\
6 & $193.2 \mathrm{a}$ & $168.6 \mathrm{a}$ & $150 \mathrm{a}$ & $139.4 \mathrm{~b}$ \\
7 & $150 \mathrm{~b}$ & $150 \mathrm{ab}$ & $118.2 \mathrm{~b}$ & $104.8 \mathrm{~cd}$ \\
8 & $142.2 \mathrm{bc}$ & $110.8 \mathrm{~b}$ & $61.4 \mathrm{c}$ & $93.33 \mathrm{~d}$ \\
9 & $133.2 \mathrm{bc}$ & $107.2 \mathrm{~b}$ & $39.6 \mathrm{~d}$ & $51.6 \mathrm{e}$ \\
Mean number of sclerotia per isolate & $131.47 \mathrm{a}$ & $122.2 \mathrm{a}$ & $84.8 \mathrm{~d}$ & - \\
\hline
\end{tabular}

${ }^{1}$ Mean number of sclerotia per $\mathrm{pH}$ value for the three isolates combined, ${ }^{2}$ Mean number of sclerotia per isolate for all $\mathrm{pH}$ values combined, ${ }^{*} \mathrm{LSD}(\mathrm{pH} \times S$. rolfsii isolates $)=25.806$ sclerotia at $P \leq 0.05$, ${ }^{*}$ For each isolate and each mean number of sclerotia (per $\mathrm{pH}$ value or per isolate), values followed by the same letter are not significantly different according to Duncan Multiple Range test (at $P \leq 0.05$ ).

The dry weight of 100 sclerotia, noted after 21 days of incubation on PDA medium, was significantly (at $P \leq 0.05$ ) affected by $\mathrm{pH}$ values and isolates tested. A significant interaction was also noted between these two factors. In fact, the highest weight of 100 sclerotia was noted on Sr1 cultures grown on PDA adjusted at $\mathrm{pH}$, those of Sr2 cultured at $\mathrm{pH}$ 4-7 and those of $\mathrm{Sr} 3$ formed at $\mathrm{pH}$ 5-6. However, at pH 9, the dry weight of 100 sclerotia was significantly the lowest for $\mathrm{Sr} 1, \mathrm{Sr} 2$ and $\mathrm{Sr} 3$ isolates and was estimated at $29.63,23.21$, and $33.37 \mathrm{mg}$, respectively (Table 4). For all pH values combined, Sr3 isolate showed the highest dry weight of 100 sclerotia as compared to the two others (Table 4).

Effect on sclerotial germination: The germination of $S$. rolfsii sclerotia, recorded after $24 \mathrm{~h}$ of incubation at $30^{\circ} \mathrm{C}$ on PDA medium, varied significantly (at $P \leq 0.05$ ) depending on tested $\mathrm{pH}$ values and pathogen isolates and on their interactions (Table 5). In fact, the optimum $\mathrm{pH}$ range for sclerotial germination was determined as 4-9 for Sr2 isolate. However, the highest percentage of sclerotial germination was recorded at $\mathrm{pH}$ values 5,7 , and 9 for $\mathrm{Sr} 1$ isolate and at $\mathrm{pH}$ $5,7,8$, and 9 for Sr3. Moreover, a total germination of 
sclerotia of all isolates was noted after $72 \mathrm{~h}$ of incubation (data not shown). For all pH values combined, the highest sclerotial germination (88.67\%) was recorded for Sr3 isolate, followed by $\mathrm{Sr} 2$ and $\operatorname{Sr} 1$ (77 and 67.33\%, respectively).

Table 4. Effect of pH of Potato Dextrose Agar medium on the dry weight of 100 sclerotia produced by three Sclerotium rolfsii isolates after 21 days of incubation at $30^{\circ} \mathrm{C}$ in the dark.

\begin{tabular}{|c|c|c|c|c|}
\hline \multirow{2}{*}{ pH value } & \multicolumn{3}{|c|}{ Dry weight of 100 sclerotia (mg) } & \multirow{2}{*}{$\begin{array}{l}\text { Mean dry weight of } 100 \\
\text { sclerotia per } \mathrm{pH}(\mathrm{mg})^{1}\end{array}$} \\
\hline & Sr1 & Sr2 & Sr3 & \\
\hline 4 & $38.37 \mathrm{~b}$ & $30.61 \mathrm{ab}$ & $36.55 \mathrm{de}$ & $35.18 \mathrm{bc}$ \\
\hline 5 & 39.17 b & $31.85 \mathrm{ab}$ & $54.86 \mathrm{a}$ & $41.96 \mathrm{a}$ \\
\hline 6 & $45.34 \mathrm{a}$ & $34.9 \mathrm{a}$ & $50.56 \mathrm{ab}$ & $43.6 \mathrm{a}$ \\
\hline 7 & $34.93 \mathrm{bc}$ & $32.67 \mathrm{ab}$ & $46.7 \mathrm{bc}$ & $38.1 \mathrm{~b}$ \\
\hline 8 & $29.37 \mathrm{c}$ & $28.49 \mathrm{bc}$ & $42.57 \mathrm{~cd}$ & $33.48 \mathrm{c}$ \\
\hline 9 & $29.63 \mathrm{c}$ & $23.21 \mathrm{c}$ & $33.37 \mathrm{e}$ & $28.74 \mathrm{~d}$ \\
\hline $\begin{array}{l}\text { Mean dry weight of } 100 \text { sclerotia pe } \\
\text { isolate }(\mathrm{mg})^{2}\end{array}$ & $36.13 \mathrm{~b}$ & $30.29 \mathrm{c}$ & $44.10 \mathrm{a}$ & - \\
\hline
\end{tabular}

${ }^{1}$ Mean dry weight of 100 sclerotia per $\mathrm{pH}$ value for the three isolates combined, ${ }^{2}$ Mean dry weight of 100 sclerotia per isolate for all $\mathrm{pH}$ values combined, ${ }^{*} \mathrm{LSD}(\mathrm{pH} \times S$. rolfsii isolates $)=4.89 \mathrm{mg}$ at $P \leq 0.05$, ${ }^{*}$ For each isolate and each mean dry weight of 100 sclerotia (per $\mathrm{pH}$ value or per isolate), values followed by the same letter are not significantly different according to Duncan Multiple Range test (at $P \leq 0.05$ ).

Table 5. Effect of pH of Potato Dextrose Agar medium on the sclerotial germination of three Sclerotium rolfsii isolates noted after $24 \mathrm{~h}$ of incubation at $30^{\circ} \mathrm{C}$ in the dark.

\begin{tabular}{ccccc}
\hline \multirow{2}{*}{ pH value } & \multicolumn{3}{c}{ Sclerotial germination (\%) } & Mean sclerotial germination \\
\cline { 2 - 4 } & Sr1 & Sr2 & Sr3 & per pH (\%) ${ }^{1}$ \\
\hline 4 & $54 \mathrm{c}$ & $78 \mathrm{a}$ & $78 \mathrm{c}$ & $70 \mathrm{~d}$ \\
5 & $70 \mathrm{ab}$ & $84 \mathrm{a}$ & $88 \mathrm{abc}$ & $80.67 \mathrm{bc}$ \\
6 & $58 \mathrm{bc}$ & $76 \mathrm{a}$ & $86 \mathrm{bc}$ & $73.33 \mathrm{~cd}$ \\
7 & $72 \mathrm{ab}$ & $70 \mathrm{a}$ & $98 \mathrm{a}$ & $80 \mathrm{bc}$ \\
8 & $66 \mathrm{bc}$ & $76 \mathrm{a}$ & $88 \mathrm{abc}$ & $76.67 \mathrm{bcd}$ \\
9 & $84 \mathrm{a}$ & $78 \mathrm{a}$ & $94 \mathrm{ab}$ & $85.33 \mathrm{a}$ \\
Mean sclerotial germination per isolate $(\%)^{2}$ & $67.33 \mathrm{c}$ & $77 \mathrm{~b}$ & $88.67 \mathrm{a}$ & - \\
\hline
\end{tabular}

${ }^{1}$ Mean sclerotial germination per $\mathrm{pH}$ value for the three isolates combined, ${ }^{2}$ Mean sclerotial germination per isolate for all $\mathrm{pH}$ values combined, ${ }^{*} \mathrm{LSD}(\mathrm{pH} \times \mathrm{S}$. rolfsii isolates $)=10.404 \%$ at $P \leq 0.05$, ${ }^{*}$ For each isolate and each mean of sclerotial germination (per $\mathrm{pH}$ value or per isolate), values followed by the same letter are not significantly different according to Duncan Multiple Range test (at $P \leq 0.05$ ).

\section{Effect of aeration on $S$. rolfsii growth and survival}

Effect on radial mycelial growth: Mycelial growth of $S$. rolfsii colonies, formed after 3 days of incubation on PDA medium, was significantly (at $P \leq 0.05$ ) influenced by aeration treatments and fungus isolates. Moreover, a significant interaction was also noted between these two factors. As indicated in table 6, S. rolfsii isolates were shown able to grow under all aeration conditions tested. The optimal radial mycelial growth of $S$. rolfsii of PDA medium occurred in unsealed, $1 / 2$ sealed and $2 / 3$ sealed plates for $\mathrm{Sr} 1$, whereas $\mathrm{Sr} 2$ and $\mathrm{Sr} 3$ exhibited their highest mycelial growth in $2 / 3$ sealed plates, and in $1 / 2$ and $2 / 3$ sealed plates, respectively. For all aeration treatments combined, the highest mycelial growth was noted on $\mathrm{Sr} 1$ cultures.

Effect on sclerotial formation and production: As indicated in table 7 , tested aeration treatments affected sclerotial formation. In fact, white sclerotia were formed at the $3^{\text {rd }}$ day of incubation in $1 / 2,2 / 3$ and no sealed plates. They appeared as whitish, tiny and pinhead-like structures, whereas mature sclerotia became brownish at the 6-9th day of incubation. However, sclerotial development was very slow in completely sealed plates where the formation of dark brown sclerotia was noted only after 15 days of incubation (Table 7). After 21 days of incubation, S. rolfsii sclerotial production was significantly affected by the tested aeration treatments, pathogen isolates and their interactions. In fact, as indicated in table 8 , the highest numbers of sclerotia were noted Sr1 cultures grown in $1 / 2,2 / 3$ and no sealed plates (445.8, 465.4, and 455.4 mature sclerotia/plate, respectively), while those of Sr2 and Sr3 formed significantly more sclerotia in unsealed plates with an average of 405.4 and 323.6 mature sclerotia/plate, 
respectively. However, all $S$. rolfsii isolates produced very few mature sclerotia in completely sealed plates. For all aeration treatments combined, $\mathrm{Sr} 1$ isolate produced significantly more sclerotia than Sr2 and Sr3 (Table 8).

Table 6. Effect of aeration treatments on the radial mycelial growth of three Sclerotium rolfsii isolates recorded on PDA medium after 3 days of incubation at $30^{\circ} \mathrm{C}$ in the dark.

\begin{tabular}{|c|c|c|c|c|}
\hline \multirow{2}{*}{ Aeration treatment } & \multicolumn{3}{|c|}{ Radial growth (mm/day) } & \multirow{2}{*}{$\begin{array}{l}\text { Mean radial growth per } \\
\text { aeration treatment }(\mathrm{mm} / \text { day })^{1}\end{array}$} \\
\hline & Sr1 & Sr2 & Sr3 & \\
\hline No sealing & $23.83 \mathrm{a}$ & $22.32 \mathrm{~b}$ & $22.09 \mathrm{~b}$ & $22.75 \mathrm{bc}$ \\
\hline $1 / 2$ sealing & $23.77 \mathrm{a}$ & $22.38 \mathrm{~b}$ & $23.07 \mathrm{a}$ & $23.07 \mathrm{~b}$ \\
\hline $2 / 3$ sealing & $23.86 \mathrm{a}$ & $24.17 \mathrm{a}$ & $23.14 \mathrm{a}$ & $23.72 \mathrm{a}$ \\
\hline Complete sealing & $22.68 \mathrm{~b}$ & $22.57 \mathrm{~b}$ & $21.89 \mathrm{~b}$ & $22.38 \mathrm{c}$ \\
\hline Mean radial growth per isolate $(\mathrm{mm} / \text { day })^{2}$ & $23.53 \mathrm{a}$ & $22.86 \mathrm{~b}$ & $22.55 \mathrm{~b}$ & - \\
\hline
\end{tabular}

Table 7. Effect of aeration treatments on the sclerotial development of three Sclerotium rolfsii isolates on PDA medium noted after 21 days of incubation at $30^{\circ} \mathrm{C}$ in the dark.

\begin{tabular}{|c|c|c|c|c|}
\hline \multirow{2}{*}{ Aeration treatment } & \multirow{2}{*}{ Isolate } & \multicolumn{3}{|c|}{ Days after incubation } \\
\hline & & First initials & White sclerotia & Dark mature sclerotia \\
\hline \multirow{3}{*}{ No sealing } & Sr1 & - & 3 & 6 \\
\hline & $\mathrm{Sr} 2$ & - & 3 & 9 \\
\hline & Sr3 & - & 3 & 9 \\
\hline \multirow{3}{*}{$1 / 2$ sealing } & Sr1 & - & 3 & 6 \\
\hline & Sr2 & - & 3 & 9 \\
\hline & Sr3 & - & 3 & 9 \\
\hline \multirow{3}{*}{$2 / 3$ sealing } & Sr1 & - & 3 & 6 \\
\hline & Sr2 & - & 3 & 9 \\
\hline & Sr3 & 3 & 6 & 9 \\
\hline \multirow{3}{*}{ Complete sealing } & Sr1 & 3 & 9 & 15 \\
\hline & Sr2 & 3 & 9 & 15 \\
\hline & Sr3 & 3 & 9 & 12 \\
\hline
\end{tabular}

Table 8. Effect of aeration treatments on the number of sclerotia produced by three Sclerotium rolfsii isolates on PDA medium after 21 days of incubation at $30^{\circ} \mathrm{C}$ in the dark.

\begin{tabular}{llllc}
\hline \multirow{2}{*}{ Aeration treatment } & \multicolumn{3}{c}{ Number of sclerotia per plate } & Mean number of sclerotia \\
\cline { 2 - 4 } per aeration treatment $^{1}$ & Sr1 & Sr2 & Sr3 & $394.8 \mathrm{a}$ \\
No sealing & $455.4 \mathrm{a}$ & $405.4 \mathrm{a}$ & $323.6 \mathrm{a}$ & $319.73 \mathrm{~b}$ \\
$1 / 2$ sealing & $445.8 \mathrm{a}$ & $261.8 \mathrm{~b}$ & $251.6 \mathrm{~b}$ & $321.53 \mathrm{~b}$ \\
$2 / 3$ sealing & $465.4 \mathrm{a}$ & $258.4 \mathrm{~b}$ & $240.8 \mathrm{~b}$ & $144.47 \mathrm{c}$ \\
Complete sealing & $147.8 \mathrm{~b}$ & $212.61 \mathrm{c}$ & $73 \mathrm{c}$ & \\
Mean number of sclerotia per isolate ${ }^{2}$ & $378.6 \mathrm{a}$ & $284.55 \mathrm{~b}$ & $222.25 \mathrm{c}$ & - \\
\hline
\end{tabular}

${ }^{1}$ Mean number of sclerotia per aeration treatment for the three isolates combined, ${ }^{2}$ Mean number of sclerotia per isolate for all aeration treatments combined, ${ }^{*}$ LSD (Aeration treatments $\times S$. rolfsii isolates) $=33.92$ sclerotia at $P \leq 0.05$, *For each isolate and each mean number of sclerotia (per aeration treatment or per isolate), values followed by the same letter are not significantly different according to Duncan Multiple Range test (at $P \leq 0.05$ ).

The dry weight of 100 sclerotia, formed after 21 days of incubation on PDA at $30^{\circ} \mathrm{C}$, varied significantly (at $P \leq 0.05$ ) depending on isolates used and tested aeration treatments; sa significant interaction was also noted between both fixed factors. In fact, Table 9 shows that, for Sr1 isolate, the highest dry weight of 100 sclerotia was recorded in $1 / 2$ sealed, no sealed and completely sealed plates. For $\mathrm{Sr} 2$, the highest records were noted in $1 / 2$ and $2 / 3$ sealed plates. For $\mathrm{Sr} 3$, the greatest dry weight of 100 sclerotia was recorded in $1 / 2,2 / 3$ and completely sealed plates. For all aeration treatments 
combined, the highest dry weight of 100 sclerotia was noted on Sr3 cultures (Table 9).

Effect on sclerotial germination: Germination of $S$. rolfsii sclerotia, noted after $24 \mathrm{~h}$ of incubation at $30^{\circ} \mathrm{C}$, did not vary significantly depending on isolates and aeration treatments tested. Furthermore, no significant interaction was recorded between these both fixed factors. The noted average of sclerotial germination ranged between 90 and $100 \%$ for all treatments and all $S$. rolfsii isolates (data not shown).

Table 9. Effect of aeration treatments on the dry weight of 100 sclerotia produced by three Sclerotium rolfsii isolates on PDA medium after 21 days of incubation at $30^{\circ} \mathrm{C}$ in the dark.

\begin{tabular}{llllc}
\hline \multirow{2}{*}{ Aeration treatment } & \multicolumn{2}{c}{ Dry weight of 100 sclerotia $(\mathrm{mg})$} & \multicolumn{2}{c}{$\begin{array}{c}\text { Mean dry weight of } 100 \text { sclerotia } \\
\text { per aeration treatment (mg) }\end{array}$} \\
\cline { 2 - 4 } & Sr1 & Sr2 & Sr3 & $47.8 \mathrm{a}$ \\
No sealing & $40.9 \mathrm{ab}$ & $44.06 \mathrm{~b}$ & $58.43 \mathrm{~b}$ & $52.29 \mathrm{a}$ \\
1/2 sealing & $42.31 \mathrm{ab}$ & $51.1 \mathrm{ab}$ & $63.46 \mathrm{ab}$ & $52.68 \mathrm{a}$ \\
2/3 sealing & $36.11 \mathrm{c}$ & $54.22 \mathrm{a}$ & $67.72 \mathrm{ab}$ & $52.48 \mathrm{a}$ \\
Complete sealing & $47 \mathrm{a}$ & $36.08 \mathrm{c}$ & $74.37 \mathrm{a}$ & \\
Mean dry weight of 100 sclerotia per & $41.58 \mathrm{c}$ & $46.36 \mathrm{~b}$ & $65.99 \mathrm{a}$ & -
\end{tabular}

${ }^{1}$ Mean dry weight of 100 sclerotia per aeration treatment for the three isolates combined, ${ }^{2}$ Mean dry weight of 100 sclerotia per isolate for all aeration treatments combined, ${ }^{*}$ LSD (Aeration treatments $\times$ S. rolfsii isolates) $=7.199 \mathrm{mg}$ at $P \leq 0.05$, *For each isolate and each mean of dry weight of 100 sclerotia (per aeration treatment or per isolate), values followed by the same letter are not significantly different according to Duncan Multiple Range test (at $P \leq 0.05$ ).

\section{DISCUSSION}

S. rolfsii is a polyphagous soilborne pathogen attacking extensive plant hosts in the world. Some studies were focused on its morphology, physiology and pathogenicity and others were more concentrated on the effect of diverse environmental factors on its growth and survival. As soil $\mathrm{pH}$ is one of these important factors, the present study investigated, in part, the effect of $\mathrm{pH}$ of medium culture on mycelial growth, sclerotial formation, production and germination of three Tunisian isolates of S. rolfsii.

In the current study, all three $S$. rolfsii isolates were shown able to grow over a range of $\mathrm{pH}$ values ranging from 4 to 9 as indicated in previous studies (Deacan, 1984; Hussain et al., 2003). The response of tested isolates was slightly different as optimal growth occurred at $\mathrm{pH} 6$ for $\mathrm{Sr} 2$ and $\mathrm{Sr} 3$ and at $\mathrm{pH} 6$ and 7 for Sr1. However, for all isolates, mycelial growth was significantly restricted at $\mathrm{pH}$ 9. These results are in agreement with those of Kumar et al. (2008) and Zape et al. (2013), reporting optimal mycelial growth at $\mathrm{pH}$ 6-7, and those of Sarker et al. (2013) who defined this optimum at $\mathrm{pH}$ range 5-6. Moreover, the restriction of pathogen growth at higher $\mathrm{pH}$ values $(\mathrm{pH}$ 9) confirmed previous studies reporting that $S$. rolfsii mycelial growth was markedly less above pH 8 (Aycock, 1966; Sharma and Kaushal, 1979; Punja, 1985).

In the same sense, dry mycelial growth was optimum at
$\mathrm{pH}$ values ranging between 4 and 7 but lowest at $\mathrm{pH} 9$. This finding is in agreement with Basamma et al. (2012) study reporting that the maximum dry mycelial weight of the fungus was noticed at $\mathrm{pH} \mathrm{5,4}$ and 6. The effect of $\mathrm{pH}$ on fungal dry biomass was also examined in another study where the exposure $S$. rolfsii to $\mathrm{pH} 5$ produced maximum mycelial dry weight as compared to $\mathrm{pH} 6$ (Muthukumar and Venkatesh, 2013b). Furthermore, in another work, vegetative growth of $S$. rolfsii was optimum at $\mathrm{pH} 3$ and was greatly reduced below 2.1 and above 5.2 (Abeygunawardena and Wood, 1957).

Sclerotial initiation started on the $3^{\text {rd }}$ day of incubation at all $\mathrm{pH}$ values tested and white immature sclerotia were observed on the 6-9 $9^{\text {th }}$ days and the $9^{\text {th }}$ day of incubation at $\mathrm{pH}$ 4-8 and $\mathrm{pH} 9$, respectively. Therefore, mature sclerotia were formed early after 6 to 12 days at $\mathrm{pH}$ range 4-6 and on the $12^{\text {th }}$ day at $\mathrm{pH}$ 7-9. After 21 days of incubation at $30^{\circ} \mathrm{C}$, all isolates showed optimal sclerotial production at $\mathrm{pH}$ 5. A similar sclerotial yield was recorded at $\mathrm{pH} 4$ for $\mathrm{Sr} 3$ isolate. Nevertheless, the lowest sclerotial density was observed at $\mathrm{pH}$ 9. This finding confirmed a previous study (Sarker et al., 2013) reporting that $\mathrm{pH} 5$ was more favourable to the sclerotial formation of $S$. rolfsii and less at $\mathrm{pH}$ 5.5. Furthermore, Abeygunawardena and Wood (1957) mentioned that the highest growth and sclerotial production occurred under the $\mathrm{pH}$ range of 2.8-7.8. In another study, $\mathrm{pH}$ values varying between 5.5 and 7.5 are optimal for sclerotial 
formation where the highest number of sclerotia was noted on cultures grown at pH 7 (Zape et al., 2013). However, sclerotial production was considered as excellent at pH levels 6, 6.5, and 7, good at pH 5 and 5.5, fair at $\mathrm{pH} 4.5,7.5$, and 8, very poor at $\mathrm{pH} 8.5$, and nil at $\mathrm{pH}$ 9 (Kumar et al., 2008).

In the current study, the highest dry weight of 100 sclerotia was recorded at $\mathrm{pH} 6$ for $\mathrm{Sr} 1$, at $\mathrm{pH}$ 4-7 for $\mathrm{Sr} 2$ and at $\mathrm{pH}$ 5-6 for $\mathrm{Sr} 3$, but at $\mathrm{pH} \mathrm{9,} \mathrm{sclerotial} \mathrm{weight} \mathrm{was}$ the lowest for all isolates. This finding confirmed a previous study reporting that dry weight of $S$. rolfsii sclerotia was similar at $\mathrm{pH} 4.5,5,6$, and 6.5 with the lowest dry weight noted at pH 7.5 (Sarker et al., 2013).

Furthermore, the optimum sclerotial germination, noted after $24 \mathrm{~h}$ of incubation at $30^{\circ} \mathrm{C}$ on PDA medium, was noted at $\mathrm{pH}$ range 4-9 for $\mathrm{Sr} 2$ isolate, at $\mathrm{pH}$ 5, 7, and 9 for $\mathrm{Sr} 1$ and at $\mathrm{pH} 5,7,8$, and 9 for Sr3. For all isolates, sclerotia germinated at $100 \%$ after $72 \mathrm{~h}$ of incubation. Nevertheless, previous studies reported that $S$. rolfsii sclerotia did not germinate above $\mathrm{pH} 7$ on agar media, but under field conditions (in soil), it occurred at $\mathrm{pH}$ values as high as 8.7 (Punja, 1982). Another study also indicated that sclerotial germination for two $S$. rolfsii isolates was greater in acid soils than in alkaline ones (Shim and Starr, 1997).

As well as for $\mathrm{pH}$, the effect of aeration treatments on $S$. rolfsii growth and survival was also investigated. In the present study, the suitability of in vitro aeration for the fungus growth at $30{ }^{\circ} \mathrm{C}$ was evaluated. In fact, optimal mycelial growth occurred in unsealed, $1 / 2$ and $2 / 3$ sealed plates for $\mathrm{Sr} 1$, whereas $\mathrm{Sr} 2$ and $\mathrm{Sr} 3$ showed their maximum mycelial extension in $2 / 3$ sealed and in $1 / 2$ and $2 / 3$ sealed plates, respectively. These results are in agreement with those of Punja (1985) who demonstrated that $S$. rolfsii mycelial extension is limited by low oxygen concentrations to a greater extent on soil than on agar. Therefore, the pathogen was considered as an air-loving organism with a more favourable development in sandy soils (Taubenhaus, 1919).

Sclerotial initiation was observed at the $3^{\text {rd }}$ day of incubation as expressed by the production of white sclerotia in $1 / 2,2 / 3$ and no sealed plates, whereas mature sclerotia became brownish at the 6-9 $9^{\text {th }}$ days of incubation. Nevertheless, sclerotial development was found to be very slow in completely sealed plates where dark brown sclerotia were observed only after 15 days of incubation. These results are in agreement with those of Muthukumar and Venkatesh (2013b) study reporting that sclerotial formation is directly influenced by aeration as completely sealed plates failed to produce sclerotia after 12 days of incubation. Formation of sclerotial initials in cultures was reported to be inhibited by oxygen concentrations below $15 \%$ or carbon dioxide above $1 \%$ or 4\% (Griffin and Nair, 1968; Kritzman et al., 1977). Therefore, a proper aeration is essential for the development of sclerotia. It is already known that sclerotial development and severity of pathogenesis were highest in sandy soils which are more aerated compared to heavy soils as less aeration hinders the formation of abundant sclerotia (Maurya et al., 2010).

As for mycelial growth and sclerotial formation, the aeration was also evaluated for its effect on sclerotial production. In fact, the highest sclerotial yields were noted on Sr1 cultures grown in $1 / 2,2 / 3$ and no sealed plates, while Sr2 and Sr3 isolates formed significantly more sclerotia in unsealed plates. However, all $S$. rolfsii isolates produced very few mature sclerotia in completely sealed plates. These findings are in accordance with those of Maurya et al. (2010) and those of Muthukumar and Venkatesh (2013a) who did not note any significant difference in the number of sclerotia between aeration treatments but only when compared to completely sealed plates. However, in this study, the highest dry weight of 100 sclerotia for Sr1 isolate was recorded in $1 / 2$ sealed, no sealed and completely sealed plates, while that of the Sr2 isolate was noted in $1 / 2$ and $2 / 3$ sealed plates. For $\mathrm{Sr} 3$ isolate, the maximum dry weight of 100 sclerotia was recorded in $1 / 2,2 / 3$ and completely sealed plates. Nevertheless, other researchers reported that the weight of 100 sclerotia was higher in unsealed plates (Maurya et al., 2010).

In the current study, sclerotial germination of $S$. rolfsii did not vary significantly depending on aeration treatments and pathogen isolates. The average sclerotial germination, noted after $24 \mathrm{~h}$, ranged from 90 to $100 \%$ for all isolates. However, in another study, germination of sclerotia was considerably increased in aerated soils (Abeygunawardena and Wood, 1957).

\section{CONCLUSION}

This study has identified some factors that have an effect on the physiology of Tunisian $S$. rolfsii isolates. The investigation of the trends for mycelial growth, sclerotial production and germination at different $\mathrm{pH}$ values and aeration treatments can provide important information about the effect of environmental conditions on the different critical stages of pathogen life cycle. Therefore, our study has contributed to the understanding of the 
ecology and physiology of $S$. rolfsii isolates under controlled conditions $(\mathrm{pH}$ and aeration). However, further investigations into the effect of other environmental factors on pathogen development under field conditions would provide a greater understanding of the biology of local $S$. rolfsii isolates.

\section{FUNDING ACKNOWLEDGEMENTS}

This work was funded by the Ministry of Higher Education and Scientific Research in Tunisia through the funding assigned to UR13AGR09-Integrated Horticultural Production in the Tunisian Centre-East, The Regional Research Centre on Horticulture and Organic Agriculture of Chott-Mariem, University of Sousse, Tunisia.

\section{REFERENCES}

Abeygunawardena, D. V. W. and R. K. S. Wood. 1957. Factors affecting the germination of sclerotia and mycelial growth of Sclerotium rolfsii Sacc. Transactions of the British Mycological Society, 40: 221-31.

Anahosur, K. H. 2001. Integrated management of potato Sclerotium wilt caused by Sclerotium rolfsii. Indian Phytopathology, 54: 158-66.

Anderson, P. K., A. A. Cunningham, N. G. Patel, F. J. Morales, P. R. Epstein and P. Daszak. 2004. Emerging infectious diseases of plants: Pathogen pollution, climate change and agrotechnology drivers. Trends in Ecology and Evolution, 19: 535-44.

Aycock, R. 1966. Stem rot and other diseases caused by Sclerotium rolfsii: or the status of rolfs' fungus after 70 years. Technical Bulletin/North Carolina Agricultural Experiment Station. pp. 136-202.

Ayed, F., H. J. Khiareddine, R. A. B. Abdallah and M. D. Remadi. 2018. Effect of temperatures and culture media on Sclerotium rolfsii mycelial growth, sclerotial formation and germination. Journal of Plant Pathology and Microbiology, 09: 429.

Banyal, D. K., V. Mankotia and S. K. Sugha. 2008. Soil characteristics and their relation to the development of tomato collar rot caused by Sclerotium rolfsii. Indian Phytopathology, 61: 10307.

Basamma, K., K. Naik, C. Madhura and L. Manjunath. 2012. Cultural and physiological studies on Sclerotium rolfsii causing Sclerotium wilt of potato. International Journal of Plant Sciences, 7: 216-19.

Boulila, M. 2001. Le dépérissement de l'olivier issu de boutures herbacées en Tunisie. EPPO Bulletin, 31: 111-12.
Daami-Remadi, M., H. Jabnoun-Khiareddine, H. Ayed and M. El Mahjoub. 2007. First report of Sclerotium rolfsii causing a typical soft rot on potato tubers in Tunisia. Tunisian Journal of Plant Protection, 2: 5962.

Daami-Remadi, M., H. Jabnoun-Khiareddine, A. Sdiri and M. El Mahjoub. 2010. Effect of temperature on Sclerotium rolfsii mycelial growth and rot severity on potato tubers. The African Journal of Plant Science and Biotechnology, 4: 54-58.

Deacan, J. W. 1984. Introduction to Modern Mycology Blackwell Scientific Publications: Oxford, UK.

Elad, Y. and I. Pertot. 2014. Climate change impacts on plant pathogens and plant diseases. Journal of Crop Improvement, 28: 99-139.

Fery, R. L. and P. D. Dukes. 2002. Southern blight (Sclerotium rolfsii Sacc.) of cowpea: Yield-loss estimates and sources of resistance. Crop Protection, 21: 403-08.

Gaaliche, B., S. Chehimi, S. Dardouri and M. R. Hajlaoui. 2017. Health status of the pear tree following the establishment of Fire blight in Northern Tunisia. International Journal of Fruit Science, 18: 85-98.

Gomori, G. 1955. Preparation of buffers for use in enzyme studies. In, Methods in Enzymology Academic Press: New York, USA.

Griffin, D. M. and N. G. Nair. 1968. Growth of Sclerotium rolfsii at different concentration of oxygen and carbon dioxide. Journal of Experimental Botany, 19: 812-16.

Hibar, K., M. Daami-Remadi and M. El Mahjoub. 2007. First report of Pectobacterium carotovorum subsp. carotovorum on tomato plants in Tunisia. Tunisian Journal of Plant Protection, 2: 1-6.

Hussain, M. A., M. Q. Khan, R. Asghar, K. Rehman, N. Hussain, T. Habib, M. DAR and H. Shaheen. 2003. Genetic relationship analysis of wild (Olea cuspidata wall.) and cultivated olive (Olea europaea L.) growing in Azad Jammu and Kashmir, Pakistan. Applied Ecology and Environmental Research, 15: 1255-67.

Jabnoun-Khiareddine, H., N. Ibrahim, R. Aydi Ben Abdallah, M. Mars, Z. Kthiri and M. Daami-Remadi. 2018. First report of Coniella granati causing dieback and fruit rot of pomegranate in Tunisia. New Disease Reports, 37: 17.

Kalai-Grami, L., M. Mnari-Hattab, R. Terres, M. Dridi and M. R. Hajlaoui. 2013. First report of apple collar rot 
incited by Sclerotium rolfsii in Tunisia. Journal of Plant Pathology, 95: 71.

Kator, L., Z. Y. Hosea and O. D. Oche. 2015. Sclerotium rolfsii: Causative organism of southern blight, stem rot, white mold and sclerotia rot disease. Annals of Biological Research, 6: 78-89.

Kritzman, G., I. Chet and Y. Henis. 1977. Effect of carbon dioxide on growth and carbohydrate metabolism in Sclerotium rolfsii. Journal of General Microbiology, 100: 167-75.

Kumar, R., P. Mishra, G. Singh and C. S. Prasad. 2008. Effect of media, temperature and $\mathrm{pH}$ on growth and sclerotial production of Sclerotium rolfsii. Annals of Plant protection Sciences, 16: 531-32.

Maurya, S., U. Singh, R. Singh, A. Singh and H. Singh. 2010. Role of air and light in sclerotial development and basidiospore formation in Sclerotium rolfsii. Journal of Plant Protection Research, 50: 206-09.

McCarter, S. M. 1984. Diseases limiting production of jerusalem artichokes in Georgia. Plant Disease, 68: 299-302.

Mordue, J. E. M. 1988. Corticium rolfsii: CMI descriptions of pathogenic fungi and bacteria. Mycopathologia, 103: 167-86.

Muthukumar, A. and A. Venkatesh. 2013a. Effect of light and aeration on the growth of Sclerotium rolfsii in vitro. African Journal of Biotechnology, 12: 684346.

Muthukumar, A., and Venkatesh, A. 2013b. Physiological studies of Sclerotium rolfsii Sacc. causing collar rot of peppermint. African Journal of Biotechnology, 12: 6837-42.

OECD. 2015. Agriculture and climate change (September 2015). Paris.

Punja, Z. 1985. The biology, ecology, and control of
Sclerotium rolfsii. Annual Review of Phytopathology, 23: 97-127.

Punja, Z. K. 1982. Effects of inorganic salts, carbonatebicarbonate anions, ammonia, and the modifying influence of $\mathrm{pH}$ on sclerotial germination of Sclerotium rolfsii. Phytopathology, 72: 635-39.

Radhouane, L. 2013. Climate change impacts on North African countries and on some Tunisian economic sectors. Journal of Agriculture and Environment for International Development, 107: 101-13.

Rhouma, A., M. A. Triki, S. Krid, J. J. Tuset and M. Msallem. 2010. First report of a branch dieback of olive trees in Tunisia caused by a Phoma sp. Plant Disease, 94: 636-36.

Sarker, B. C., S. K. Adhikary, S. Sultana, A. Biswas and S. F. D. Azad. 2013. Influence of $\mathrm{pH}$ on growth and sclerotia formation of Sclerotium rolfsii causal agent of foot rot disease of betel vine. Journal of Agriculture and Veterinary Science, 4: 67-70.

Sharma, S. L. and B. R. Kaushal. 1979. Cultural and physiological studies with sunflower isolate of Sclerotium rolfsii. Indian Journal of Mycology and Plant Pathology, 9: 105-07.

Shim, M. Y. and J. L. Starr. 1997. Effect of soil pH on sclerotial germination and pathogenicity of Sclerotium rolfsii. Peanut Science, 24: 17-19.

Singh, A. and H. B. Singh. 2004. Control of collar rot in mint (Mentha spp.) caused by Sclerotium rolfsii using biological means. Current science, 87: 362-66.

Taubenhaus, J. J. 1919. Recent studies on Sclerotium rolfsii Sacc. Journal of Agricultural Research, 18: 127-38.

Zape, A. S., R. M. Gade and R. Singh. 2013. Physiological studies on different media, $\mathrm{pH}$ and temperature on Sclerotium rolfsii isolates of soybean. Scholarly Journal of Agricultural Science, 2: 238-41.

Publisher's note: EScience Press remains neutral with regard to jurisdictional claims in published maps and institutional affiliations.

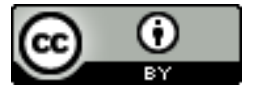

Open Access This article is licensed under a Creative Commons Attribution 4.0 International License, which permits use, sharing, adaptation, distribution and reproduction in any medium or format, as long as you give appropriate credit to the original author(s) and the source, provide a link to the Creative Commons license and indicate if changes were made. The images or other third-party material in this article are included in the article's Creative Commons license, unless indicated otherwise in a credit line to the material. If material is not included in the article's Creative Commons license and your intended use is not permitted by statutory regulation or exceeds the permitted use, you will need to obtain permission directly from the copyright holder. To view a copy of this license, visit http://creativecommons.org/licenses/by/4.0/.

(C) The Author(s) 2018. 